\title{
Coffee Consumption-A Genetic Approach
}

\section{Roseane $\mathrm{M}$ Santos $^{1, *}$ and Lima DRA ${ }^{2}$}

Department of Pharmaceutical Sciences, South University School of Pharmacy, 709 Mall Boulevard, Room 341, Savannah, GA 31419, USA

Instituto of Neurology, Federal University of Rio de Janeiro, Brazil

\section{Introduction}

Coffee is among the most widely consumed beverages in the world. The consumption of coffee has been receiving a lot of attention in regards its potential health benefits and risks as well. Caffeine and phenolic compounds such as chlorogenic acids are some of the most investigated constituents from coffee. It has been attributed various properties to those compounds such as central nervous system stimulant and antioxidants respectively. Coffee is in fact a very complex mixture that varies according with the origin of the beans and roasting process.

A new approach to look into possible effects of drugs is through genetic and genomic studies. Recently it was created The Coffee and Caffeine Genetics Consortium with the purpose to identify DNA loci associated with habitual coffee consumption. The technique utilized is called genome-wide meta-analysis (GWMA)[1]. Caffeine has been the center of attention in those studies [2,3], but the data that is being collected started showing a complex network of gene transcription regulation that will probably lead us to a broader picture of the profile of the regular coffee consumer.

It is a common belief that people avoid drinking coffee because of its effects.Caffeine content in coffee is responsible for the effects experienced, since the common complaints are hand shaking, increase in the heart rate and anxiety [4-6]. CYP1A2 accounts for approximately $95 \%$ of caffeine's metabolism and shows genetic polymorphism that reflects the variability in enzyme activity between individuals [7]. It displays a polymorphic genetic binomial distribution within the population. The homozygous wild type confers a fast metabolizer phenotype and the homozygous variant allele confers a slow metabolism of caffeine. The latter being the least predominant in the normal population[8]. In a pilot study, we evaluated whether the individuals that have the polymorphic variant genotype $(1 \mathrm{~A} 2 * 1 \mathrm{~F})$ for caffeine metabolism (CYP 1A2) would show higher levels of caffeine in plasma after consumption of one cup of coffee. Secondly, we used a questionnaire to examine if the caffeine metabolism phenotype status of an individual influences their habitual coffee consumption[6]. The results did indicate an inverse relationship between caffeine metabolism (CYP 1A2) and plasma caffeine levels but the sample population was too small to correlate with coffee consumption habits.

New studies are showing the involvement of many other loci within the genome, either located at the same fragment of CYP 1A2 gene, chromosome 15, but also at other fragments not necessarily at the same chromosome and in non-coding regions with regulatory effect on CYP 1A2 expression and other genes as well [5,9-16].

It is our goal to continue genetic studies of coffee consumption, which is considered as a genetic trait (NCBI database) such as DNA fragments rs16868941 (Chr.8); rs12148488, rs6495122, rs762551, rs2470893 (Chr.15) as well as caffeine trait (rs1051730; rs1378942 at Chr.15) $[16,9,10]$. It is our understanding that we are very close to start unveiling this intricate network of regulatory effects of specific genomic regions that are inherited from our parents and the environmental influence within coffee consumers and nonconsumers.

\section{Publication History:}

Received: December 29, 2016

Accepted: January 28, 2017

Published: January 31, 2017

\section{Keywords:}

Coffee, Consumption, Genome, Health, Effect

\section{Competing Interests}

The authors declare that they have no competing interests.

\section{References}

1. Cornelis MC, Monda KL, Yu K, Paynter N, Azzato EM, et al. (2011) Genome-wide meta-analysis identifies regions on $7 \mathrm{p} 21$ (AHR) and 15q24 (CYP1A2) as determinants of habitual caffeine consumption. PLoS genetics 7: e1002033.

2. Josse AR, Da Costa LA, Campos H, El-Sohemy A (2012) Associations between polymorphisms in the AHR and CYP1A1-CYP1A2 gene regions and habitual caffeine consumption. Am J Clin Nutr 96: 665-671.

3. Rasmussen BB, Brix TH, Kyvik KO, Brosen K (2002) The interindividual differences in the 3-demthylation of caffeine alias CYP1A2 is determined by both genetic and environmental factors. Pharmacogenetics 12: 473-478.

4. Cornelis MC, El-Sohemy A, Campos H (2004) Genetic polymorphism of CYP1A2 increases the risk of myocardial infarction. J Med Genet 41: 758762.

5. Cornelis MC, El-Sohemy A, Campos H (2007) Genetic polymorphism of the adenosine $\mathrm{A} 2 \mathrm{~A}$ receptor is associated with habitual caffeine consumption. Am J Clin Nutr 86: 240-244.

6. Santos RM, Cotta K, Jiang S, Lima DRA (2014) Does CYP1A2 Genotype influence coffee consumption? Austin J Pharmacol Ther 3: 1065

7. Sachse C, Brockmoller J, Bauer S, Roots I (1999) Functional significance of a C-->A polymorphism in intron 1 of the cytochrome P450 CYP1A2 gene tested with caffeine. British journal of clinical pharmacology 47: 445-449.

8. Han XM, Ou-Yang DS, Lu PX, Jiang CH, Shu Y, et al. (2001) Plasma caffeine metabolite ratio $(17 \mathrm{X} / 137 \mathrm{X})$ in vivo associated with $\mathrm{G}-2964 \mathrm{~A}$ and C734A polymorphisms of human CYP1A2. Pharmacogenetics 11: 429-435.

9. Amin N, Byrne E, Johnson J, Chenevix-Trench G, Walter S, et al. (2012) Genome-wide association analysis of coffee drinking suggests association with CYP1A1/CYP1A2 and NRCAM. Mol Psychiatry 17:1116-1129.

10. Cornelis MC, Byrne EM, Esko T, Nalls MA, Ganna A, et al. (2014) Genomewide meta-analysis identifies six novel loci associated with habitual coffee consumption. Mol Psychiatry 20: 647-656.

11. Jia H, Aw W, Egashira K, Takahashi S, Aoyama S, et al. (2014) Coffee intake mitigated inflammation and obesity-induced insulin resistance in skeletal muscle of high-fat diet-induced obese mice. Genes Nutr 9: 389.

"Corresponding Author: Prof. Roseane M. Santos, Department of Pharmaceutical Sciences, South University School of Pharmacy, 709 Mall Boulevard, Room 341, Savannah, GA 31419, Tel: 912-201-8131 USA; E-mail: rsantos@southuniversity.edu

Citation: Santos RM, Lima DRA (2016) Coffee Consumption-A Genetic Approach. Int J Clin Pharmacol Pharmacother 2: 124. doi: https://doi. org/10.15344/2017/2456-3501/124

Copyright: (c) 2016 Santos et al. This is an open-access article distributed under the terms of the Creative Commons Attribution License, which permits unrestricted use, distribution, and reproduction in any medium, provided the original author and source are credited. 
12. McMahon G, Taylor AE, Davey Smith G, Munafò MR (2014) Phenotype refinement strengthens the association of AHR and CYP1A1 genotype with caffeine consumption. PLoS One 9: e103448.

13. Palatini P, Ceolotto G, Ragazzo F, Dorigatti F, Saladini F, et al. (2009) CYP1A2 genotype modifies the association between coffee intake and the risk of hypertension. J Hypertens 27: 1594-1601.

14. Santos RM, Lima DR (2016) Coffee consumption, obesity and type 2 diabetes: a mini-review. Eur J Nutr 55: 1345-1358.

15. Yang A, Palmer AA, de Wit $\mathrm{H}$ (2010) Genetics of caffeine consumption and responses to caffeine. Psychopharmacology (Berl) 211: 245-257.

16. Sulem P, Gudbjartsson DF, Geller F, Prokopenko I, Feenstra B, et al. (2011)

Sequence variants at CYP1A1-CYP1A2 and AHR associate with coffee consumption. Hum Mol Genet 20 :2071-2077. 